Volume 4

Number 1 July

Article 1

$7-31-2020$

\title{
Foreword from Handling Editor - 7th Edition
}

Astari Dwiranti

astari.dwiranti@sci.ui.ac.id

Follow this and additional works at: https://scholarhub.ui.ac.id/ajce

Part of the Social and Behavioral Sciences Commons

\section{Recommended Citation}

Dwiranti, Astari (2020). Foreword from Handling Editor - 7th Edition. ASEAN Journal of Community Engagement, 4(1).

Available at: https://doi.org/10.7454/ajce.v4i1.1097

Creative Commons License

cc) (i) (2)

This work is licensed under a Creative Commons Attribution-Share Alike 4.0 License.

This Front Matter is brought to you for free and open access by the Universitas Indonesia at ASEAN Journal of Community Engagement. It has been accepted for inclusion in ASEAN Journal of Community Engagement. 


\section{Foreword from Handling Editor - 7th Edition}

\section{Dear Readers,}

It is very happy for us to present this edition, Volume 4 Number 1, July 2020. Amid the concerns of the Covid-19 pandemic, which influences human life around the globe, we are honor to select and publish the best submitted-papers in the field of community engagement (5 papers from Indonesia, 3 Papers from Philippines, 1 Paper from Portugal, 1 Paper from Australia, 1 Paper from Thailand, and 1 Paper from Malaysia and Vietnam).

At the first insight, we present an article with type of Research Paper, Review Articles, and Casebased Articles. For Research Paper, we have excellent of 8 articles. First article about creative economy clinic. The authors: Andri Zainal, T. Citra Nisa Farza, Khairunnisa Harahap, and Pasca Dwi Putra writes, "Developing an on-campus creative economy clinic to elevate the quality of existing community service program". The article is to highlights the potential outcomes of establishing an in-campus creative economy clinic that ensuring the business sustainability of MSMEs in the disruptive technology era. Initial assessment related to the needs of MSME is further required as a strategic step for the development of the ecosystem of related creative economy clinic based on competitive advantage attached to each university

Next, we present the paper an enriching creative communities through literature, "Enriching creative communities through young adult (YA) literature: a content analysis of zines from Philippine High School for the Arts" written by Reya Mari Soriaga Veloso. This article conclude that YA zines provide alternative creative community to the youth, are a form of counterstorytelling, and a means for sociological theorizing - all of which are necessary functions for enriching creative communities among the youth.

On the topic of health, we present articles by the author Hugo Oliveira and Jorge Bonito. with the title "Health education projects in Portuguese schools: A multicases study". Authors presents there is a lack of instruments and methodologies able to record the behavioral changes developed within the scope of health education, while simultaneously stimulating the reflection on these behavioural changes and their causes.

Next article, still with Research Paper, written by Sri Ismiyati Damayanti, Simparmin Ginting, Otik Nawansih, and Siti Hudaidah, with the article "Implementation of biogas-based energy security program and evaluation of its sustainability in Kediri Village, Pringsewu District, Lampung Province". Authors concluded that the Biogas-based Energy Security Program has succeeded in making the community awareness, accept and apply the technology of processing cow manure into biogas, where the people whose houses have biogas flow, all the fuel needs for cooking and electricity off, $100 \%$ have been met by biogas.

A discussion of current issues about Covid-19 written by Yeni, Najmah, and Sharyn Graham Davies. The paper "Predicitive modeling, empowering women, and Covid-19 in South Sumatra, Indonesia" shows modelling indicates that over 1,000 people had Covid-19 by the end of April, reaching over 150,000 by the end of May, and over a third of South Sumatra's population is likely 
to be infected by the end of June. Multiple interventions are needed to reduce cases and flatten the curve. Women are key to flattening the curve and must be empowered to undertake actions from a familial base.

On the topic of kids related to protection, we present a paper "Self protection and stop bullying campaign for kids at RPTRA Sungai Bambu, Tanjung Priok, Jakarta Utara” written by Suraya Mansur. The result shown that children who take part in community service activities shown an increase level of knowledge and awareness of self-protection by following the instructions in the song "Sentuhan Boleh Sentuhan Tidak Boleh" (What You Can Touch, and What You Can't Touch). These approach must be done together with other friends, for more mature children to guide younger children.

Another article from health, is written by Artemio Morado Gonzales Jr. The article "Empowering the lowland indigenous community through child health and nutrition program in Occidental Mindoro Province, Philippines". The common tools used from this article were seating arrangement, flipcharting, props, social hours, and recreation. In terms of the evaluation of the program, the child health remains poor despite of the effort of the different blocks that is working in the health system. Thus, this program could enhance their health knowledge and practice in other forms of extension modalities.

Development of technology for dairy cattle production, is discussed in a paper entitled "Intensifying forage legumes strata system technology through dairy cattle production" written by Marcos E. Bollido, Teresa B. Polbos, and Feleciano R. Bejar. These technologies was implemented in collaboration with the Department of Agriculture and Local Government Unit of San Jorge, Samar. Beneficiaries were selected based on the set criteria and qualifications.

For Review Articles we have 3 selected papers. First, about Social Life Cycle Assessment (SLCA) is written in the article "Enhancing the community engagement of Indonesian Palm Oil Companies through the implementation of the Social Life Cycle Assessment (SLCA)" by Indah Budiani. The study highlights importance of community stakeholders' inclusion in decisionmaking processes as the means to prevent conflict, and to maintain company reputation. Other approaches such as capacity building and social economic development can be also effective as long as there is a thorough assessment in advance and participation of local community in developing the intervention plan.

Next article is from Thailand with the topic of cross-border development in Universities, with the title "Cross-border development - a long-term role for Universities" by Robert Brian Smith and Nucharee Nuchkoom Smith. The results showed that there are three issues were identified as priority areas to be addressed: quality of higher education, complex government bureaucracies and ineffective on the job training. This will require universities to provide high quality offerings which are relevant to their community and the wider world market.

Third article for Review Article is written by Ma Tin Cho Mar and Pham Huong Trang, with the title of "Malay minorities in The Tenasserim coast". This paper discussed Malay Minorities in the 
Tenasserim Coast and then Tanintharyi Division is an administrative region of Myanmar at present. This study methodology combined two complementary approaches for identifying, analyzing and understanding patterns of knowledges sharing within complex social systems. Furthermore, the paper discussed the significance attached to the aspects of human migration in Southeast Asia.

Last one article for Case-based Articles is written by Hanna Lianti, Novi Kurnia, Kshetra Rinaldhy, Amanda Safira Aji, M Febriadi Ismet, and Rizky Amaliah. This article about knowledge regarding Biliary Atresia, with the title of "Analysis of knowledge regarding Biliary Atresia among healthcare providers and laypersons in East Jakarta after educational intervention". The result are there were significant increase in the median value between pre-test and post-test knowledge scores in both healthcare providers and laypersons groups.

We want to express our thanks to the Directorate of Community Engagement and Empowerment, Universitas Indonesia, and reviewers who gave inputs and contributions to improve the quality of the articles. Our greatest thanks are also due to Azhar Firdaus for helping us with the publication process and to the Directorate of Administration, Data, and Management of Research Product and Innovation (DADPPRI UI) for providing a journal development grant and proofread assistance through Enago. Finally, we hope that readers enjoy the articles that we present in this edition.

We hope that readers enjoy exploring the papers on this edition and keep healthy and safe.

Best Regards,

Astari Dwiranti, Ph.D.

Handling Editor - ASEAN Journal of Community Engagement

https://scholarhub.ui.ac.id/ajce/ 